\title{
INOVATYVIEJI FRANÇOIS JULLIENO PSICHOANALIZĖS KONCEPTAI KINIŠKOSIOS MINTIES REFLEKSIJOS ŠVIESOJE
}

\author{
François Jullien's Innovative Concepts for Psychoanalysis \\ in the Light of Chinese Thought Reflection
}

\begin{abstract}
SUMMARY
The article explores developed by a French philosopher, sinologist François Julien psychoanalytic concepts, which are suggested to be used for a more accurate description of the logic of the psychoanalytical process and its components. This results in a deeper effect of the unthought-of (Fr. impensé). The author explains S. Freud's theoretical psychoanalysis and its elements through the lens of extracts from Mencius, Confucius, Sunzi's and other thinkers' works, as well as images of the Chinese worldview. There, a greater emphasis is placed not on the "cold", rational origin, but on the processual emotional interpretation, characterized by its situativity, adaptation to the relativity of the situation, and decisions, often made based on the ongoing circumstances, without the declaration of the termination of the situation. Offered by F. Jullien concepts enrich psychoanalysis with a deeper and more nuanced specificity of treatment, as well as offer new valuable connotations to Freud's theoretical principles of psychoanalysis.
\end{abstract}

\section{SANTRAUKA}

Straipsnyje analizuojami prancūzų filosofo, sinologo François Jullieno sukurti teoriniai psichoanalitinių tyrinèjimų konceptai, kuriuos jis pasitelkè, norẻdamas tiksliau apibrėžti psichoanalitinio pažinimo proceso logiką bei atskirus jo sudedamuosius segmentus, siekiant gilesnio ir neapmąstyto (pr. impensé) pažinimo efekto. Mokslininkas remiasi S. Freudo taikytos teorinės psichoanalizės bei jos praktinių sandų filosofiniu aiškinimu, pasitelkdamas i pagalbą Mencijaus, Konfucijaus, Sunzi ir kt. kinų mąstytojų filosofemas bei kiniškosios pasaulèjautos vaizdinius, kuriuose dažniausiai vyrauja ne blaivus racionalus pradas, o iš Yijing („Permainų knygos“) idèjų pasaulio kylanti kinų mąstymo tradicijai būdinga vyksmo kaip nesibaigiančio

RAKTAŽODŽIAI: komparatyvistinė filosofija, F. Jullienas, kinų mąstymas, S. Freudas, psichoanalizė, neapmąstytas. KEY WORDS: comparative philosophy, F. Jullien, Chinese thought, S. Freud, psychoanalysis, the unthought-of. 
proceso traktuotė. Ji orientuota i kinų mąstymo tradicijos išpuoselètą situatyvumą, kontekstualumą, reliatyvizmą, priimant sprendimus, kurie dažniausiai priimami atsižvelgiant i konkrečias besiklostančias aplinkybes ir nepretenduojant į vienareikšmį susiklosčiusios situacijos baigties konstatavimą. F. Jullieno išplètoti iš psichoanalizès problemų lauko kylantys filosofiniai teoriniai ir metodologiniai konceptai papildo psichoanalizę gilesniu ir detalesniu psichikos sutrikimu gydymo specifikos išgryninimu bei plètoja naujas vertingas konotacijas Freudo apibrěžtiems teoriniams psichoanalizės principams.

\section{IVADAS}

İtakingas prancūzu sinologas ir komparatyvistas Francois Jullienas sukūrè naują kritini filosofinès analizès metodą ir kontekstualiu kategorijų sistemą, remdamasis kinu mąstymo tradicijos, rašto savitumo veiktu pasaulèvaizdžiu, susietu su psichoanalizės pradininko Sigmundo Freudo išplètotos metodologijos principais. Kinu tradicija ir laimèjimai sinologijos srityje Jullienui yra svarbus pagalbinis i̇rankis, leidžiantis suabejoti Vakaru mąstymo tradicijoje išplètotu filosofiniu kategoriju universalumu. "Norint patirti, kokia gali būti minties dezorientacija (pr. dépaysement)“, autorius siūlo skaitytojui pasitelkti kinų kultūrą kaip išorés tašką (turimas omenyje kritinis Vakaru minties vertinimas iš neeuropinès, sekuliarios bei kontekstualios mąstymo tradicijos). Dèl šios išorés (pr. dehors) ir todèl, kad kinų mąstymo tradicija plètojosi lygiagrečiai Europos kultūrai ir jos filosofijai, bei, kas labai svarbu, nebuvo jokios abipusès itakos, autorius tam tikrose kinų filosofijos sąvokose randa nauju žiūros tašku, leidžiančių suvokti tai, kas mūsu „,neapmąstyta“ (pr. impensé). Taigi jis vykdo Vakarų mąstymo tradicijos dekonstrukciją iš išorès, kurią sudaro nukrypimas nuo nusistovejusių minties prielaidu, Vakaru ideologijos, neišvengiamai perteikiančios kalbą ir etimologija per kitas sąvokas, itvirtintas kitoje tradicijoje ir kita kalba. Anot Jullieno, norint padaryti aplinkkeli (pr. détour) per Kinija, reikia bandyti sukurti ịstriža (pr. prise), strategini požiūrì, kuris „išverčia“ europini mąstymą i i išvirkščią pusę ir atskleidžia jo akląsias zonas, apmirusius kampus.

Lokalesnio pobūdžio Jullieno konceptai, gvildenantys psichoanalizės problemas, radosi iš apmąstymų, kilusių diskutuojant psichiatru ir psichoanalitiku konferencijose, kuriose pakviestas dalyvaudavo bei dalijosi iš daugiamečio darbo sinologijos ir komparatyvistikos srityse gautomis kinu filosofinès minties ¡žvalgomis. Tuo tarpu pats autorius psichoanalitinès metodologijos principus pažinęs per skaitytus Freudo tekstus, kuriais remdamasis jis siūlo psichoanalitikams vartoti 5 kertines sąvokas, kilusias iš kitu (neeuropinių) kontekstų ir kviečia konceptus vartoti taip, kaip patinka, atsižvelgiant i plètojamą problemą bei klausimą.

Jullienas issitikinęs, kad Freudo teorinis aiškinimas liko kitapus tuometiniu atradimu, dèl kuriu pavyko pacientus išgydyti praktiškai. Anot jo, toks teorijos vèlavimas praktikos atžvilgiu yra susijęs su kalba ir Europos filosofinėmis tradicijomis, kurios užrakino mąstymą tam 
tikroje logikoje (jos rèmuose) ir neleido jam plètotis platesniu spektru ir skatinti spartesnę praktinès psichoanalizès pažangą. Taigi visos pastangos sugriauti klasikinę priežastį arba ją revoliucionizuoti turi ribas, kurias galbūt gali padèti ìveikti kita kalba, kita tūkstantmẽtè tradicija. Kiekvienu atveju priartinti kinų kalbą ir kultūrą prie europinio mąstymo bei psichoanalizès - tai Jullieno siekis, ambicija.

Nenuginčijama tiesa, kad gydymo procesas ir pats nesamoningo (pr. l'inconscient) atradimas sujaukè protu ir sąmone pagristą Europos minties paveldą XIX ir $X X$ a. sandūroje. Jullieno atradimai suteikia galimybę pamatyti tai, kad nepaisant Freudo vykdomos revoliucijos ir jo išrastų konceptų, pats Freudas lieka ka- liniu, atsakingu už klasikinès minties kategorijas - būtent priklausomu nuo europinio mąstymo instrumentarijaus. Natūraliai kyla klausimas, kaip i̇manoma igyvendinti neivykdytas užduotis liekant racionaliame, sąmone pagrịstame Vakaru pasaulyje. Taigi prancūzų filosofas, sinologas, helenistas Jullienas savo darbe Penki psichoanalizei pasiūlyti konceptai (pr. Cinq concepts proposés à la psychanalyse) pateikia daug naujų konceptų, kuriuose, jo manymu, galètú atsispindèti, kas vyksta gydymo metu, ir jie padètų detaliau paaiškinti šio proceso eigą. Tokiu būdu už tam tikrų mažai išplètotų Freudo sampratų Jullienas izžvelgia psichoanalizès "neapmastyto" (pr. impensé) žymę, kurią i dienos šviesą ištraukia gydymas.

\section{KINŲ MĄSTYMU GRĮSTI JULLIENO KONCEPTAI PSICHOANALIZEI}

\section{Prieinamumas}

Prieinamumas (pr. la disponibilité) yra pirmasis autoriaus siūlomas konceptas. Pasak jo, šis terminas leidžia nušviesti froidiškają sampratą (sąvoką) plaukiojantis demesys (pr. l'attention flottante), kuri apibrèžia psichoanalitiko poziciją gydant, kitaip tariant, tai yra technine taisyklè, kuria vadovaudamasis gydytojas skiria vienodai dèmesio viskam, ką sako analizuojamasis ir nesuteikia ypatingos reikšmės vienai detalei kitos detalès sąskaita. Froido instrukcija buvo tokia: nesirinkti tarp analizuojančiojo diskurso elementų tų, kurie atrodo svarbūs, o vietoje to - priimti viska, kas pasakyta, be jokio išankstinio nusistatymo. Tačiau Kinijoje vartojama prieinamumo sąvoka leidžia eiti toliau plètojant ši požiūrį: ši pozicija, išlaikyta kaip išminčiaus prerogatyva, panaši i praradima (la déprise), tačiau panaši ne tuo vakarietiškuoju (froidiškuoju) abejojimu, kuris prieštarauja išankstinems nuostatoms, o greičiau atsisakymu sustoti ties vienu matymo tašku: „laimèjimas per pralaimèjimą“ (pr. Prise par déprise) (Jullien 2019: 26). Psichoanalitiko požiūris ị kintantį dèmesi yra panašus į išminčiaus, kai jis atitinkamai stengiasi nieko neišskirti, kad nepraleistu to, kas gali nutikti (psichoanalizès atveju - suteikti esminès informacijos dèl analizuojamojo pasąmoniniame lygmenyje esančių fiksacijų i traumos momenta, inicijuojančių neurozių pasireiškimą bei aplinkybių atsikartojimą analizuojamojo sapnuose, isteriju priepuoliuose ir t. t.) ${ }^{1}$. 
Psichoanalitiko plaukiojančiojo demesio pozicijos apibrěžtis ,,$<\ldots>$ nereiškia nei skrydžio, nei abejingumo, nei mieguistumo, nei neryžtingumo ar dvejonių... Tai taip pat nereiškia nuotaikos ìvaldymo. Suformuotoji lygybė rodo tiek analizuojamojo, tiek psichoanalitiko pusiausvyrą ir būtinybę, kad pastarasis atsiribotų nuo savo kasdienių rūpesčių, paliktų nuošalyje tai, kas motyvuoja jo veikla, pamirštú iprastus moralinius išankstinius nusistatymus, savas teorines prielaidas bei kitas nuomones ir tokiu būdu būtų prieinamas" (Megglé 2007). Jullienas prieinamumo konceptą taiko psichoanalitiko plètojamo kontakto su analizuojamuoju santykiui nušviesti akcentuodamas psichoanalitiko dèmesio svarbą.

Apibendrinant psichoanalitiko, kaip išminčiaus / ne-išminčiaus traktuotę (t. y. Jullieno pasiūlytas kiniškosios minties adaptavimo psichoanalizei variantas), darytina logiška išvada, jog paties Freudo jo gyvenamuoju periodu taikytos pasichoanalizès metodai išties būtų siejami su psichoanalitiko, kaip viskąa žinančio, strateguojančio ir netgi nukreipiančio analizuojamajj psichoanalitikui reikiama kryptimi, vaizdiniu. Tačiau pofreudiškojo laikotarpio psichoanalizè evoliucionavo tiek, jog teko praplèsti ne tik psichoanalizejje taikomų teorijų ir metodų kiekį, bet ir pripažinti tokių teorijų bei metodų efektyvumą. Taigi kai kuriose naujose teorijose bei taikomose psichoanalizès terapijose keitèsi ir psichoanalitiko vaidmens traktuotè. Todèl natūralu, kad XIX-XX a. sandūroje psichoanalitikas ar gydytojas Freudo taikytose praktikose galejo atitikti kinų išminčiaus vaizdini, tačiau keičiantis, evoliucionuojant meto- dikoms, jis tapo lygiaverčiu analizuojamajam kognityvinio proceso aplinkoje užimdamas ne visažinio, o greičiau „dalyvaujančio stebètojo" poziciją"2.

\section{Aliuziniškumas}

Antrasis konceptas yra aliuziniškumas (pr. l'allusivité) - terminas, kuriuo Jullienas pasinaudojo motyvacijai psichoanalizès srityje apibrèžti siekdamas paaiškinti netiesioginès prieigos procesą kalboje. Ši terminą Jullienas taiko aiškindamas pagrindinę gydymo, kai analizuojamasis pasako viska, kas jam ateina i galva, taisyklę. Aliuziniškumo samprata siejama su analizuojamojo diskursu (šneka), kadangi padeda ligoniui apipinti jam psichoanalitiko patikètą leksinį vienetą gausiomis asociacijomis.

Aliuziniškumas, apie kurị kalba ir kuri pats Jullienas anksčiau konceptualizavo kinų poezijai, padeda suvokti numanoma, aiškiai nepasakoma analizuojamame diskurse (paciento kalboje). Pasitelkiant laisvųju asociacijų metoda, galima numatyti, kad analizuojamojo diskursas neitų tiesiai i savo tiksla, kad nuoroda būtų aiškiai nepasakoma, kad aplinkkelis (per. détour) būtų būtinas atskleidžiant, nušviečiant užslopinimą (išstūmima ì pasąmonę (vok. Verdrängung): tai, kas išstumta, yra nesąmoningų reiškinių pavyzdys), bet ypač kad analizuojamasis pasiduoda nežinojimui, ką jis kalba, kad jis palieka savieigai savą diskursa, kurio tikslas jam akivaizdžiai „,išslysta“. Remdamasi taisykle „pasakyti viska, kas ateina i galvą", psichoanalizè šizart siūlo tam tikro pobūdžio analizuojamojo informacini "praradima" (per. déprise) tam, kad būtų atrasta tikroji problemos priežastis. 
Jullienas aiškiai rodo, kaip ši kalbos koncepcija prieštarauja tái, kuri yra sukurta vakarietiškosios kultūros. Be kita ko, jis primena, kad klasikiné filosofija, ir ypač Aristotelio, Europos protą grindė tuo, jog kalba yra pateisinama tik tuo atveju, kai ji turi ką pasakyti, t. y. kai ji turi objektą.

Kiniškasis mąstymas kaip toks nesiremia kalbos racionalumo principu. Ypač taoistų mąstyme rekomenduojama kalbèti „pagal norą", t. y. būtent tai, ką Laozi vadina kalbèjimu be kalbejjimo (pr. parler sans parler, kin. yan wu yan) (Jullien 2019: 57), kur kalba visai nèra būtinai priskiriama prie objekto. Taoistine kalba informuoja be informavimo, ji leidžia prasmei ateiti per aliuziją. Jullienas teigia, jog žodžiai yra laisvi nuo bet kokių tikslų nekalbama siekiant suteikti atitinkamą Ł̇vardijima, pavadinima, leidžiama laukti neapibrěžtą laiką tam, kad nebūtų pažeista tai, kas turi būti suprasta. Remiantis šiuo požiūriu, bandyti neišlaukus „pačiupti reikšmę " - tai tas pat kaip ją "sukirsti“" nepasiekus tikslo.

Tokiu būdu susisiejantys aliuziniškumo konceptas ir visas kinų mąstymas prisideda prie pasąmonés atradimo tiek, kad ji suardo klasikini sąryši tarp subjekto ir kalbėsenos bei diskurso. Taigi Jullieno sukurtasis konceptas orientuotas i analizuojamojo paciento diskurso apibrèžti. Vertètų prisiminti vieną prieštaringiausių prancūzu psichoanalitiku ir psichiatru J. M. É. Lacana, kuris teige, jog „nesąmoningumas yra tokia pat struktūra kaip ir kalba" (pr. l'inconscient est structuré comme un langage) (Lacan 1981: 20). Aliuziniškumas yra neatsiejama psichoanalizès metu analizuojamojo diskursui taikoma api- brèžtis, kadangi šią akimirką sąmoningai suvokiamas vaizdinys kitą akimirką jau gali būti suvokiamas prasčiau, tačiau tam tikromis aplinkybèmis jis gali būti bet kada sugražintas $i$ samonę ${ }^{3}$.

\section{Netiesumas, nukrypimas ir poveikis}

Netiesumas (suktumas) (pr. le biais), nukrypimas (aplinkkeliškumas) (pr. l'oblique) ir poveikis (pr. l'influence) - visi šie terminai sudaro vientisą trečiojo Jullieno nagrinejjamo psichoanalizès koncepto branduoli bei yra taikomi metodo tikslui (siekiui) nusakyti. Trys pastarieji minimi psichoanalizės konceptai yra orientuoti i konkretu atitinkamo metodo taikymo metu formuojamą sieki - ambicija, kuriai igyvendinti reikalingas atitinkamų priemonių paciento atžvilgiu naudojimas.

Autorius bando atsakyti i klausima, kaip apibūdinti psichoanalitiko metoda, jo intervenciją i gydymą kaip nuoseklią elgsena, tačiau tuo pačiu ne projekcinę (pastaroji neretai orientuota i testų taikymą) ar paremtą režimo ir vaistu skyrimu. Taigi kaip sugalvoti veikimo būda, kuris būtų neginčijamas, tikslus, bet ne metodiškas (turima omeny - taikomas ne visiems bendrai)? Iš tiesu šimtmečiais trukusi epistemologinè (gnoseologinè) detalizacija yra nenaudinga, netinkama psichoanalizės atveju, nes visa Vakaru mintis siekia kurti veiksmų ir žiniu modeli. Tad koki sprendimą siūlo Jullienas?

Išeitis, pasiūlyta autoriaus, fokusuojasi ties tuo, ką jis vadina netiesumu (suktumu), nukrypimu, kitaip tariant, tai yra intervencija, kuri nèra nei frontali (kolektyvinè, taikytina masei), nei preskriptyvi 
(vaistai, režimas). Ši paralelè paaiškintų, kaip psichoanalitiko îsikišimas apeina analizuojamojo pasipriešinima, siekiant rasti individualų, vienetinị, savita, pavieni „,atakos kampą“ jo atžvilgiu bei sudarant galimybes paskatinti modifikaciją (pokyti) analizuojamojo psichikoje. Sunzi Karo mene teigia, kad „,susitikimas ivyko iš priekio, bet pergalè pasiekiama iš šono [de biais]“, t. y. taikant netiesumo kategoriją. Šis strateginis aplinkkelis (vingis) priešingas tiesioginiam poveikiui, ìsikišimui (frontaliajai intervencijai), arba kitaip ji galima pavadinti paaiškinimu, kuriuo nukreipiamas žvilgsnis ì įtikinèjimą (sugestiją), - tai, ko Freudas galiausiai XIX a. pabaigoje pats veiksmingai atsižadejjo pacientų atžvilgiu.

Netiesumas prasiskverbia, daro itaką ne tik karo strategijai, tačiau taip pat ir analitiko kalbos vartojimui (t. y. kaip specialistas vartoja kalbą). Šis požiūris atveda prie Konfucijaus idejos, kad meistras (specialistas) daro didesni poveiki savo itaka, nei kad savuoju skelbiamu mokymu. Konfucijus taip pat atsižvelgia i tai, kur yra jo pašnekovas tam, kad galètu atsidurti toje vietoje, izsikišti i esamą situacija, sutrikdyti pašnekovą (sukelti jam sumišimą) ir tokiu būdu leisti jam išeiti iš tos padèties, kurioje jis buvo iklimpęs.

Taigi anksčiau apibrèžtasis poveikis nėra vertinamas kaip įtaigos priemonè, atstumianti, atgrasinanti analizuojamąji nuo jo asmeninio mąstymo - priešingai, nei europiniame racionalume. Kinų mąstyme poveikis (pr. l'influence) netgi reprezentuoja visos esamos tikrovės pradžios, atsiradimo modeli, kadangi kiniškoje tradicijoje nemąstoma pasitelkiant būties ir identifikavimo (sutapatinimo) termi- nus, o orientuojamasi i̇ sąveikos, energijos srauto, pẽrëjimo apibrèžtis.

Kai šis gyvybinis (vitalinis) energijos srautas, šis neatskiriamas nuo gyvenimo judejjimas būna užblokuotas žmoguje, pasirodo kančia ir liga. Jullieno nuomone, tai yra būtent tie faktoriai, kurie kankina pacienta, kai jis atvyksta prašyti analizès. Jullieno mintį kartoja Freudas, teigdamas, kad žodžiu "<...> ,trauminis" apibūdiname tokị išgyvenimą dèl kurio psichikos dirginimas per trumpą laiką taip sustiprèja, kad nuo jo išsivaduoti ar ji apdoroti îprastais būdais nepavyksta, ir energijos apykaita ilgam sutrinka" (Freud 2014: 265).

Jullieno konceptų taikymas renkantis analizès metodą implikuoja, kad paciento laisvuju asociaciju metodas būna efektyvus tada, kai analizuojamasis ima apmąstyti neapmastyta (kai taikant kuri nors metodą analizuojamasis pamažu pats atranda savo pasąmoninius procesus), kitaip tariant - susiklosto sąlygos vystyti emocini intelektą (tiksliau - ji išreikšti prieš tai buvusi intrapsichini konfliktą defiksuojant iki struktūrinio asmenybès pasikeitimo): vienas jo sandas yra orientuotas i gebejjimą suprasti savas emocijas ir jas nukreipti (intrapsichinis intelektas), kitas - $\mathrm{i}$ bendravimą su žmonemis ir iš to kylančias emocijas (baimè, nerimas, smalsumas ir kt.) bei jų atpažinimą (tarpasmeninis intelektas). Metodo taikymo metu analizuojamasis igyja ižvalgą apie pasąmoninius procesus (baimes, prieštaravimus, nerima, norus, jausmus), o tai savo ruožtu veda prie intrapsichinio konflikto sprendimo, kuris turès ittakos struktūriniam asmenybès pasikeitimui ${ }^{4}$.

Laisvujų asociacijų metodą Freudas yra ivvardijęs kaip façon de parler (pr. kal- 
bèjimo būdas), čia taikoma verbalinè asociacija - psichoanalitikas pateikia analizuojamajam koki nors žodị, o šis turi sakyti tai, kas jam ateina i galvą dèl pasakyto žodžio poveikio. Štai kodèl taip svarbu, remiantis Jullieno netiesumo (pr. le biais), nukrypimo [aplinkkeliškumo] (pr. l'oblique) ir poveikio (pr. l'influence) konceptais, sekti bei veikti paciento asociaciju eigą tvarką ir reikšmę, štai kodèl tiek ypatingas gebejjimas pasukti kalbą aplink (pr. détour), kad asociacijos nenutrūktu, nes analizuojamasis kuriuo nors metu pasidaro atsargus, ima svyruoti. Psichoanalitikas, plètodamas ši metoda, privalo išlikti indiferentiškas, t. y. analizės metu neteikti jokio vertinimo. Norint išvengti panašių trikdžių, puikiai pritaikomas tam tikro lygio suktumas, aplinkkeliškumas ir, be abejo, poveikis, kuriuos metodo plètojimui siūlo Jullienas konceptualizuodamas atitinkamas sąvokas.

\section{De-fiksacija}

Analizuojamojo atžvilgiu taikomam gydymui Jullienas sukuria koncepta, kuri pavadina de-fiksacija (pr. dé-fixation). Kad ir kokia būtų numatyta (pasirinkta) gyvenimo sritis, reikia panaikinti tai, kas stabdo, užšaldo subjektą ir neleidžia jam judèti pirmyn. Štai ir dar vienas kinu mąstymo mokomas praradimo (déprise) aspektas. Turimas omenyje atitinkamas tam tikru praeities situacijų, užslèptu traumų ir skaudulių eliminavimas.

Gyvybinis vitališkasis srautas niekada neturètu sustoti, sustingti vietoje. Net dorybė gali sukelti fiksaciją (sąstingi) ir sumažinti prieinamumą. Freudas tikrai nebūtu prieštaravęs šiam moralès sugriovimui, kadangi jis manè, jog kai ku- rios "dorybès" buvo tiesiogiai kilusios iš infantilių fiksacijų (sąstingių). Prisimenant psichoanalizę - trauminių neuroziu (vok. traumatische Neurosen) priežastis yra fiksacija i traumos momentą; neretai aplinkybès, kuriomis įvyko trauma, kartojasi ligoniu sapnuose. Trauminiais taip pat vadinami tie išgyvenimai, $i$ kuriuos fiksuojasi nervu ligoniai. „Kiekviena neurozè kartu yra ir fiksacija, bet anaiptol ne kiekviena fiksacija sukelia neurozę, sutampa su neuroze ar atsiranda dèl neurozès" (Freud 2014: 266).

Jullieno aprašytasis de-fiksacijos konceptas labai glaudžiai siejasi su Freudo fiksacijos apibrèžimu vaiko psichoseksualinès raidos teorijoje, kuri teigia, jog suaugusiojo bruožus lemia vaikystės patirtis. Vaiko psichoseksualinės raidos teorija pabrèžia, kad kiekvienas žmogus pereina psichoseksualinio vystimosi pakopas, kurios būdingos visiems žmonèms; kiekvienoje ju vaikas gali patirti fiksaciją ir regresiją. FIKSACIJA - sustojimas ir užsilaikymas tam tikroje raidos pakopoje. Regresija - grižimas i ankstesnę psichoseksualinio vystymosi pakopą (Cvirkaitè 2008) $)^{5}$. Taigi „ivairūs stresiniai veiksniai gali sustabdyti raidą kuriame nors etape ir sukurti vadinamuosius fiksacijos taškus, i kuriuos jau suaugęs žmogus nesąmoningai "grižta", kad susidorotų su neiveiktais raidos stadijos reikalavimais. Tai lemia ir asmenybès savybes" (Milašiūnas 2006: 373).

Taigi ką turi omeny Jullienas, siūlydamas psichoanalizei de-fiksacijos konceptą ir ji siedamas su gydymo procesu? Kadangi esminę fiksacijos problemą lemia intrapsichinis ${ }^{6}$ konfliktas, kuri sukelia Id varu „išslydimas“ iš $E g o^{7}$ kontrolès (žmogaus "valdymo centro"), o tai nu- 
tinka neretai dèl to, jog libidinè Id vara (slypinti nesąmoningoje psichikos dalyje) veikia per malonumo principa, t. $y$. siekia kuo greitesnio pasitenkinimo per varų energijos iškrova, tai Ego struktūra, veikianti šiuo atveju kaip objektyvi ir sąmoninga, neleidžia $I d$ tiesiogiai išlieti susikaupusios energijos ir patirti malonumo ir ieško kompromisinių būdų pasitelkdama gynybos mechanizmus (kurie yra nesąmoningoje Ego dalyje). Kompromisas būtinas todèl, kad Superego struktūra, kurioje susitelkusios asmenybès vertybès ir moraliniai issitikinimai, veikia Ego žmogaus „valdymo centrą" ir šis privalo surasti kompromisinį sprendimą tarp Id ir Superego struktūrų. Jeigu spaudimas iš Superego yra labai stiprus ir Ego gynybiniai mechanizmai nebesugeba $I d$ libidinès varos energijos, nepriimtinos informacijos, traumos, išgąsčio išstumti i pasąmonę (t. y. „panardinti“ juos i „,neveiksnumo būseną"), iškyla psichikos sutrikimo simptomai ir ilgainiui žmogui prasideda nerimas, isterija, keisti nuolat besikartojantys veiksmai ir ipročiai bei kt., kadangi neišstumtoji i pasąmonę informacija suvokiama sąmoningai ir veikia analizuojamojo psichiką. Pasąmonę (neissisąmonintą psichikos turinį) nuo kitų dviejų ikisąmonès ir sąmonès struktūrų skiria „cenzoriai“ (topografinis psichikos modelis) ${ }^{8}$, tad jie ir saugo asmenybę nuo nepageidaujamų impulsų, fantazijų, stabdo tiesioginę varų energijos iškrovą. Tokiu būdu sąmonè būna saugoma nuo pernelyg didelès vidinès itampos stabdant tiesioginę libido energijos iškrovą. Aprašytoje bendro pobūdžio situacijoje veikia afekto-traumos modelis, kuris yra visų psichikos sutrikimų pagrindas. Taigi psichikos dirginimas gali tiek sustiprèti, jog nuo jo išsivaduoti ir ji apdoroti iprastais būdais nepavyksta - energijos apykaita sutrinka ilgam. Jeigu Ego struktūra pakankamai stipri, spaudimas iš Id ir Superego struktūrų nèra itin forsuojantis, tada Ego terpejje atrandami tinkami kompromisai ir pavyksta išlaikyti psichikos dinaminę pusiausvyrą. Kitu atveju, nesugebant jos išlaikyti sveikos, formuojasi psichikos sutrikimų simptomai.

Jullieno de-fiksacija koncepto taikymas šiuo atveju geriausiai apibrěžtų pasireiškiančių trauminių neurozių gydymą, kuris Freudo buvo izvardijamas kauzaline terapija - tai metodas, kuriuo siekiama pašalinti ligos priežastis. De-fiksacija atitiktų gydymą pasitelkiant perkèlimo (vok. Übertragung) ar pasipriešinimo (vok. Widerstand) procesus ${ }^{9}$ - ir vienu, ir kitu atveju vyksta vadavimasis iš vaikystëje susiformavusio fiksacijos taško (taškų), kuris žymi kadaise ìvykusi Id libidinės energijos išstūmimą (vok. Verdrängung) i pasąmonę, o kadangi kažkoks psichinis procesas nesibaige normaliai, jis negalejo tapti sąmoningas. Minètas procesas, būdamas nesąmoningas, sukūrẻ simptomą. Taigi ligonio spyriojimasis ir nepasidavimas gydymui (žiuljeniškajai de-fiksacijai) yra tos pačios prigimties kaip ir tada, kai buvo spyriojamasi, kad psichinis procesas neprasiskverbtų iki sąmonès. Tačiau sèkmingam gydymui yra būtina de-fiksacija, o pats sudètingiausias dalykas yra tai, jog ji trunka labai ilgai, tad logiškai galime daryti išvada, jog de-fiksacijos procesas yra dinamiškas reiškinys, kuris prasideda jau tada, kai yra taikomas laisvuju asociaci- 
jų metodas, kurio metu ligonis stebi (yra skatinamas psichoanalitiko) tik savo sąmonès paviršių ir yra skatinamas nepasiduoti, jei kiltų noras nutylèti ar rinktis kokią nors kitą minti vietoje tų, kurios, analizuojamojo manymu, nemalonios, nereikšmingos ar beprasmès, - tai yra techninè psichoanalizès taisyklè. Taip kuriamas ilgas de-fiksacinis procesas, kuriam būdingas nuolatinis dinamiškumas, analizuojamasis priešinasi stengdamasis apeiti būtent minètą taisyklę (šiuo atveju ligonis bando taikyti savita, destruktyvų gydymo požiūriu „aplinkkelio“ principą) ir analizuotojo tikslas - neleisti reikštis šiam principui. Vienas sunkiausių techninės psichoanalizès uždavinių ivveikti bet kokio pobūdžio analizuojamojo priešinimąsi.

Idomu, jog de-fiksacijos proceso dalis taip pat yra ir dèl „perkèlimo“ îvykęs priešinimasis gydymui ir "perkèlimo" objektui - pavyzdžiui, tèvui, kuris yra „perkeltas“ i psichoanalitiko asmeni. Tada padeda Jullieno pasiūlytas netiesumas [suktumas] ar nukrypimas [aplinkkeliškumas], siekiant gauti svarbios informacijos apie analizuojamojo praeiti bei šia lanksčia technika nukreipti priešinimąsi reikiama linkme - būtent pasiekti žiuljeniškaji poveiki, o tai juk ir buvo taikyto metodo siekis (minètieji konceptai Jullieno buvo labai taikliai priskirti prie psichoanalitiko metodinès ambicijos), skatinantis ligonio transformaciją ir grąžinantis ji prie psichikos dinaminès pusiausvyros.

Net išminčius, pasak Mencijaus (IVIII a. pr. Kr.), nesustingsta savoje pasiektoje didybèje - neturi būti galutinès stotelès, net ir esant norimai būsenai, bet, priešingai, reikia palaikyti judejima, transfor- macija, virsmą padedantị kaupti gyvenimo išteklius, galimybes, jègų atsargas.

Tokiu būdu atsiveriama troškimui, energijos pratekèjimui, judèjimui, naikinama fiksacija, kadaise tapusi analizuojamojo stabdžiu ir jo išgyvenimų panardinimo pasąmonèn priežastimi. Tame yra perversmas, artimas freudiškajam mąstymui: elgsena Kinijoje nèra nei veiksmas, nei galutinis tikslas - tai yra procesas.

\section{Tyli transformacija}

Kalbant Jullieno žodžiais, "tyli transformacija (pr. la transformation silencieuse) - tai tokia transformacija, kuri vyksta be triukšmo, taigi apie ją nekalbama. Tyli transformacija yra lètas procesas, nematomas, „povandeninis" judejimas, kuris suvokiamas (pajuntamas) po pasikeitimų rezultatų smūgio - kaip gydymo procese. Ji tylì i abi puses: [iš vienos pusès] ji veikia be perspèjimo, [iš kitos pusès] negalvojama apie tai kalbèti. Jos nepastebimumas nèra nematomas, nes ji formuojasi atvirai, prieš mūsų akis, tačiau ji nepasiduoda užčiuopimui, nustatymui. Šis [transformacijos] neatskiriamumas kyla iš sutvarkymo, bet ne iš regimumo, o iš eigos sutvarkymo; jis neišsiskleidžia erdvejje, tai vyksta laike. Tai iki tiek yra tiesa, kaip kad reiškiniu procesas, kuris tęsiasi nakties metu lygiai kaip ir šviesiu paros metu" (Jullien 2019: 131). Unikalus tylios transformacijos suvokimo, pajautimo pavyzdys yra nakties atèjimo konstatavimas: mes matome rezultata, matome fakta, netgi matome vyksma, kaip pereinama iš dienos šviesos i tamsa, tačiau tame yra kažkas neapčiuopiamo, fiziškai nepajuntamo. Sakydami „atèjo naktis" mes tegalima konstatuoti fakta, remdamiesi fizikiniais 
argumentais: sutemo, pasirodè žvaigždès ar mėnulis, visur plyti nakties tamsuma, tačiau pačios nakties mes nematome - ji plyti aplink mus, ji apčiuopiama rega, tačiau neįmanoma paliesti; ji vyksta, mes esame joje, tačiau be regèjimo vargiai galètume pasakyti, jog išvis suvokiame, kas yra naktis, kadangi mes negalime jos apčiuopti. Ji patenka tarp tokių neapčiuopiamų, abstrakčių filosofiniu požiūriu reikšminių kategorijų, tokių kaip „nelaimè", „mirtis", "laimè", "graužatis", ,pavasaris", „ruduo" - protu suvokiame, kad ji ivyko, galime netgi ivardinti konkretu atveji, tačiau pačios nelaimès (ir kt. apibrèžčių), atkeliaujančios ar išeinančios, mes niekada netgi nematėme, o gebame ją konstatuoti suteikdami îvykiams nelaimès ivvardijimą. Skirtumas tik tas, kad gamtos reiškinių nenutrūkstamas procesas ir jų virsmas yra pastebimas, juos galime priskirti prie erdvès ir laiko kategorijų, o kai kurie ivykiai atsitinka aplink mus (mirtis, laimè) ir ju transformacijos yra tylios, mes galime tik konstatuoti, jog virsmas ivvyko, matome rezultatą.

Remiantis anksčiau aptartais pavyzdžiais, minètus vyksmus, kaip ir tylia transformacija, būtų tikslinga priskirti prie laiko kategorijos konceptų (ir tam tikra prasme - prie erdvès kategorijos), juo operuojant įmanoma apibrěžti ir sunkiai nusakomus vidinius psichinius virsmus, kurie vyksta mums nematant, ju tarsi nėra, tačiau mes matome vykstanti veiksma (šiuo atveju - psichoanalizę) ir po kurio laiko konstatuojame jos rezultata, matydami ivykusią tylia transformacija analizuojamojo psichikoje.

Psichoanalizès proceso metu tyli transformacija reiškiasi nematant nei psichoanalitikui, nei analizuojamajam. Ji glaudžiausiai sietussi su veiksmo ir jo rezultato reikalavimu. Viena paskutiniųjų psichoanalizès dalių yra „paciento perauklëjimas", kai psichoanalitikui, turinčiam savo rankose visus analizès duomenis ir iqveikus paciento pasipriešinimą bei perkèlimo prisirišima, belieka pasiekti tiksla, kad pacientas suprastų, jog jo reakcijos yra nesubrendusios, infantiliškos, netinkamos jo esamai būklei, amžiui ir t. t. Taigi stengiamasi mobilizuoti visas analizuojamojo vidines pajègas, kad reakcijos taptų sveikos bei adekvačios ir neurozes kèlę veiksniai būtų negrị̌tamai pašalinti. Tokiu metu ir vyksta tyli transformacija (la transformation silencieuse), kai pasiekiamas norimas rezultatas, veiktas atitinkamų prieš tai buvusių veiksmų ir analizuojamojo pastangų.

Proceso samprata (žiuljeniškoji „proceso logika“) yra tylios transformacijos fenomeno sudedamoji dalis, kuri implikuoja eiga, t. y. laiko faktorių. Šiuo aspektu visa kinų kultūra prieštarauja Europos kultūrai. Procese yra tęstinumas, kuris priešinasi îvykiui, kuriam būdingas baigtinumas. Taigi kiniškasis mąstymas yra daugiau mąstymas apie pradžią nei apie ivvyki.

\section{IŠVADOS}

Iš atliktos analizès galime daryti pirmą principinę išvada, kad kinų mąsty- mas nèra psichoanalizè, nepaisant akivaizdaus artumo ir paskirų jam būdingu 
aspektų, kuriais Jullienas pasinaudoja detalesniam jos savitumo aiškinimui. Šis subtiliai igyvendintas aplinkkelis per Kiniją jos mąstymo tradiciją, rašto, kalbos specifiškumo išryškinimą nesumažins psichoanalitinio gydymo slèpiningumo, neišreiškiamumo ar sakralumo. Kiniškoji mąstymo tradicija ir iš jos kylanti kelis tūkstantmečius plètotès skaičiuojanti išmintis, kad ir kokia turtinga ji būtų, neturètų būti supainiota su psichoanalize, priešingai kuriai, ji žymi trū$k i$ (écart). Kita vertus, akivaizdus faktas yra tai, kad psichoanalizės ir, plačiau žvelgiant, Vakaru mąstymo tradicijos susidūrimas su šiuo aukščiausio laipsnio kitoniškumu turi nenuginčijamą euristini vertingumą kuris skleidžiasi keičiant jo paties veikiamus mąstymo ipročius.

Jullieno siūlomų konceptu psichoanalizei neapmastyto naujumas tampa svarbiu instrumentu, leidžiančiu praplèsti gana siaurus Freudo ir Vakaru mąstymo tradicijos rèmus bei dar giliau

\section{Literatūra}

Andrijauskas Antanas. 2010. Freudo santykiai su neklasikine mąstymo tradicija ir jo metafilosofijos personažai. Logos 63: 18-30. Prieiga per internetą: <https://www.mruni.eu/upload/iblock/ da7/02_Andrijausikas.pdf> [žr. 202010 08]

Cvirkaitė Kristina. 2008. Klasikinè psichoanalizè. Klinikine psichologija. Prieiga per internetą: <http://nesnausk.org/klinikine-psichologija/ 2008/09/30/sigmund-freud/> [žr. 202010 23]

Freud Sigmund. 1999. Anapus malonumo principo. Iš vokiečių k. vertė Antanas Gailius. Vilnius: Vyturys.

Freud Sigmund. 1991. Drei Abhandlungen zur Sexualtheorie. Frankfurt am Main: Fischer-Taschenbuch-Verl.

Freud Sigmund. 2014. Psichoanalizès ịvadas. Paskaitos. Iš vokiečių $\mathrm{k}$. vertė Austèja Merkevičiūtè. Vilnius: Vaga. apibrèžti ir paaiškinti psichoanalizès metodologiniu nuostatu taikymo procese matomų, analizuojamu ir nematomu virsmų visumą. "Apmastyti neapmastyta" derètu priskirti prie psichoanalizès ir apskritai to, kas vadinama Vakarų mąstymo tradicija, tuo tikslu, kad atsirastu galimybe žvelgti iš gerokai platesnių ir gilesniu poziciju, atrandant naujas konotacijas, suteikiant reiškiniams detalumo ir apmąstant aplinkkeliu, kaip kad elgiasi psichoanalitikai laisvųju asociacijų metodo taikymo metu, kai tikslas tik vienas - surasti tai, kas neatrasta, užslopinta, neiškelta i viršų ir tam tikrose situacijose veržiasi visuomeneje "neurozių" formomis, kurios šaukte šaukia, jog šimtmečiais slopintos tiesos turi būti ìvardintos sąmoningai: nauju požiūriu, gilesniu žvilgsniu, didesniu supratimu, nes, pasirodo, tai "gydo", išlaisvina iš sustabarejusių ir neginčijamų tiesu, kurias verta dar kartą peržvelgti siekiant praplèsti mūsų suvokimo ribas.

Gardner Howard. 2011. The Theory of Multiple Intelligences. New York: Basic books.

Jullien Francois. 2019. Cinq concepts proposés à la psychanalyse. Paris: Grasset.

Lacan Jacques. 1981. Le séminaire de 1955-1956. Paris: Le Seuil.

Megglé Virginie. 2007. L'attention flottante en psychanalyse. Psychanalyse en mouvement. Paris. Prieiga per internetą: <https://www.psychanalyse-en-mouvement.net/actualites/article104-20071204104-1-attention-flottante-en-psychanalyse.html> [žr. 202010 20]

Milašiūnas Raimundas. 2006. Apie autorių. Sigmund Freud, Kasdienio gyvenimo psichopatologija. Iš vokiečių k. vertė Ona Meiglienè ir Rūta Jonynaitè. Vilnius: Apostrofa. 


\section{Nuorodos}

${ }^{1}$ Detalūs trauminiu neurozių (vok. traumatische Neurosen) apibrèžimai, jų reiškimosi būdai bei psichikos procesų nagrinèjimas detaliai aprašytas: Freud Sigmund. 2014. Psichoanalizés ivvadas. Paskaitos.Iš vokiečių k. vertė Austèja Merkevičiūtè. Vilnius: Vaga, p. 263-277.

${ }^{2}$ Leskauskas Darius. Psichoanalitinè psichoterapija. Psichoanalizésstudijos.lt. Prieiga per internetą: <http://www.psichoanalizes-studijos.lt/ index.php/psichoanalize/apibrezimas> [žr. 2020 10 21]

3 Plačiau apie tai žr. Freud Sigmund. 1999. Anapus malonumo principo. Iš vokiečiu $\mathrm{k}$. vertė Antanas Gailius. Vilnius: Vyturys, p. 132.

${ }^{4}$ Daugiau apie psichoanalizès metodus ir jų taikymą bei naujausias tendencijas ieškoti dr. Dariaus Leskauskas. Psichoanalitinè psichoterapija. Psichoanalizés-studijos.lt. Prieiga per internetą:
$<$ http://www.psichoanalizes-studijos.lt/index. php/psichoanalize/apibrezimas> [žr. 202010 21]

${ }^{5}$ Detalus paaiškinimas straipsnyje, žr.: Cvirkaitė 2008.

${ }^{6}$ Intrapsichinis intelektas pirmąkart paminètas 1983 m., kai Howardas Gardneris paskelbė septynias intelekto rūšis bei savo garsiąją intelekto ivairovès teorija (The Theory of Multiple Intelligences), plačiau žr. Gardner Howard 2011.

7 Id (das Es), Ego (das Ich) ir Superego yra 3 žmogaus psichiką sudarančios struktūros, kurios yra puikiai aprašytos straipsnyje, žr.: Antanas Andrijauskas 2010.

8 Topografinis psichikos modelis pateikiamas knygoje: Sigmund Freud 1991.

${ }^{9}$ Daugiau apie perkèlimo (vok. Übertragung) ar pasipriešinimo (vok. Widerstand) procesus galima rasti: Sigmund Freud 2014 : 277-293, 425-444. 